\title{
Marker-assisted selection in breeding silkworm strains with high silk production and resistance to the densonucleosis virus
}

\author{
C.X. Hou' ${ }^{1}$, P.J. Sun ${ }^{1}$, X.J. Guo ${ }^{1,2}$, Y.P. Huang ${ }^{3}$ and M.W. Li ${ }^{1,2}$ \\ ${ }^{1}$ Sericultural Research Institute, Jiangsu University of Science and Technology, \\ Zhenjiang, China \\ ${ }^{2}$ Sericultural Research Institute, Chinese Academy of Agricultural Sciences, \\ Zhenjiang, China \\ ${ }^{3}$ Institute of Plant Physiology and Ecology, \\ Shanghai Institutes for Biological Sciences, Chinese Academy of Sciences, \\ Shanghai, China \\ Correspondence author: M.W. Li \\ E-mail: muwang_li@hotmail.com
}

Genet. Mol. Res. 12 (4): 4171-4178 (2013)

Received September 18, 2012

Accepted December 14, 2012

Published October 7, 2013

DOI http://dx.doi.org/10.4238/2013.October.7.3

\begin{abstract}
In the silkworm (Bombyx mori), resistance to the Zhenjiang (China) strain of the densonucleosis virus (DNV-Z) is controlled by the recessive gene $n s d-Z$ (non-susceptible to DNV$Z$ ), which is linked to 7 simple-sequence repeat markers. Markerassisted evaluation and selection of DNV-Z-resistant silkworms were used for predicting DNV-resistance in backcrossed animals. A silkworm race was bred using this method, and its economic characteristics were found to be similar to those of commercial silkworm races. These markers will therefore be useful for silkworm breeding
\end{abstract}


programs and in screening for densonucleosis resistance in segregating populations.

Key words: Bombyx mori; Densonucleosis virus; Non-susceptible gene; Marker-assisted selection

\section{INTRODUCTION}

The Bombyx densonucleosis virus (BmDNV) causes flacherie disease in the silkworm (Bombyx mori). BmDNV multiplies only in the nuclei of the columnar cells of the larval midgut epithelium (Seki and Iwashita, 1983; Guo et al., 1985). DNV viruses possess a small, single-stranded, linear DNA genome, and are classified into the family Parvoviridae (Lü, 1998). The parvoviruses are one of the smallest viruses with genomic DNA, and they require factors from the host cell and/or helper viruses for efficient replication (Watanabe et al., 1986; Abe et al., 1987; Goldsmith et al., 2005).

BmDNVs comprise several strains, such as the Ina, Saku, and Yamanashi viruses. As classified by Watanabe et al. (1986), the Ina virus belongs to the DNV-1 type, while the Saku and Yamanashi viruses belong to the DNV-2 type. Iwashita and Chao (1983) described the chemical characteristics of DNV-Z, and Qian et al. (1985) demonstrated that it was similar to the Saku virus.

Non-susceptibility to DNV-1 is controlled by the recessive gene $n s d-1$ and the dominant gene Nid-1 control (Eguchi et al., 1991). The $n s d-2$ and $n s d-Z$ genes confer resistance to DNV-2 and DNV-Z, respectively (Hu et al., 1984; Abe et al., 1987; Qin and Yi, 1996). Abe et al. $(1998,2000)$ identified and mapped several random-amplified polymorphic DNA (RAPD) markers linked to the $n s d-1$ and $n s d-2$ genes. Ogoyi et al. (2003) mapped $n s d-2$ using the restriction fragment length polymorphism method, and obtained 3 closely linked cDNA markers. Based on a map-based cloning analysis, Li et al. (2001a) identified an RAPD marker linked to $n s d-Z$. Furthermore, Ito et al. (2008) found that the virus resistant to BmDNV-2 was caused by a deletion in the open reading frame of an amino acid transporter.

Based on viral resistance characteristics, it has been proposed that homozygous $n s d-Z$ silkworm strains can be used in breeding to prevent economic losses due to DNV-Z. The incorporation of the $n s d-Z$ gene and the elimination of the susceptibility gene(s) during breeding programs could provide significant advantages for the production of commercial silkworm strains. Historically, DNV has been fed to silkworms during breeding to select for individuals resistant to DNV-1 or DNV-Z (Eguchi et al., 1998; Li et al., 2001b). More recently, marker-assisted selection (MAS) has been widely used in breeding programs (Yau et al., 2005; Steele et al., 2006), although, to date, it has not been applied in silkworm breeding.

Microsatellites, or simple-sequence repeats (SSRs), are short, tandemly repeated motifs of 1 to 6 bases found in all prokaryotic and eukaryotic genomes. SSRs are widely used in population genetics and linkage map construction because of their high levels of polymorphism and reproducibility (Tautz, 1989), and their genome-wide distribution. SSRs are inherited in a Mendelian fashion and show co-dominant alleles. Reddy et al. (1999) obtained 28 SSR markers and used 15 of them to estimate the relationships among 13 strains of silkworm. Miao et al. (2005) constructed a silkworm SSR linkage map. 
Li et al. (2005a,b, 2006) investigated the genetic diversity among silkworm germplasms using 26 SSR markers, and characterized 7 SSR markers linked to $n s d-Z$. In this study, we used these 7 SSR markers as tools to select silkworms that were not susceptible to DNV-Z, in order to breed non-susceptible silkworm races using an MAS approach.

\section{MATERIAL AND METHODS}

\section{Silkworm strains}

The L10 silkworm strain (nsd-Z/nsd-Z) is non-susceptible to DNV-Z, but its eco-

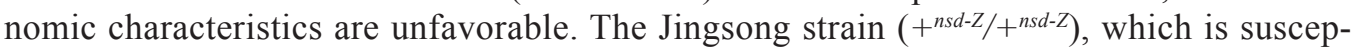
tible to DNV-Z, is a productive commercial strain widely used in Chinese sericulture. These strains were maintained at the Sericulture Research Institute, Chinese Academy of Agriculture Sciences.

\section{DNA extraction and polymerase chain reaction (PCR)}

DNA samples were extracted from whole moths and from the midgut of unhealthy larvae. The moth body (or midgut) was ground with a mechanical homogenizer in a microcentrifuge tube, and suspended in DNA extraction buffer $(50 \mathrm{mM}$ Tris- $\mathrm{HCl}, \mathrm{pH} 8.0$, $100 \mathrm{mM} \mathrm{NaCl}, 20 \mathrm{mM}$ EDTA) containing $150 \mu \mathrm{g} / \mathrm{mL}$ proteinase K. After digestion with proteinase $\mathrm{K}\left(50^{\circ} \mathrm{C}\right.$ for $\left.8-10 \mathrm{~h}\right)$, a phenol-chloroform extraction was performed, and the DNA was precipitated out with isopropanol. Purified DNA was dissolved in 0.1X TE buffer, $\mathrm{pH}$ 8.0. The DNA concentration was measured by spectrophotometry (BioPhotometer, Eppendorf), and the samples were diluted to a concentration of $10 \mathrm{ng} / \mu \mathrm{L}$ for use in PCR analysis.

The PCRs were performed using a Flexigene Cycler (Techne, UK). The following PCR conditions were used for the microsatellite loci: i) $95^{\circ} \mathrm{C}$ for $3 \mathrm{~min}, 63^{\circ} \mathrm{C}$ for $40 \mathrm{~s}$, and $72^{\circ} \mathrm{C}$ for $1 \mathrm{~min}$, followed by 14 cycles of $94^{\circ} \mathrm{C}$ for $45 \mathrm{~s}$, then a 14-step touchdown, decreasing by $0.5^{\circ} \mathrm{C}$ at each step to $56^{\circ} \mathrm{C}(40 \mathrm{~s})$, and $72^{\circ} \mathrm{C}$ for $1 \mathrm{~min}$; ii) conditions for the last 24 cycles were $94^{\circ} \mathrm{C}$ for $40 \mathrm{~s}, 56^{\circ} \mathrm{C}$ for $40 \mathrm{~s}$, and $72^{\circ} \mathrm{C}$ for $1 \mathrm{~min}$; and iii) a final elongation step of 10 min at $72^{\circ} \mathrm{C}$. The PCR was performed in a final volume of $15 \mu \mathrm{L}$, containing $10 \mathrm{mM}$ Tris- $\mathrm{HCl}$, $\mathrm{pH} 8.4,50 \mathrm{mM} \mathrm{KCl}, 1.5 \mathrm{mM} \mathrm{MgCl}, 0.2 \mathrm{mM}$ of each dNTP, $0.2 \mu \mathrm{M}$ of each primer, $20 \mathrm{ng}$ genomic DNA, 0.5 U Taq polymerase (Takara), and distilled, deionized water. PCR products at about $0.5 \mathrm{ng}(0.01 \mathrm{pM})$ per sample were analyzed using an ABI377 DNA sequencer (ABI PRISM).

\section{Strategy for MAS}

MAS was adopted to breed a new silkworm strain that is not susceptible to DNV$\mathrm{Z}$, based on co-dominant SSR markers linked to $n s d-Z$. For the crossing-over experiments, a female of the Jingsong strain was crossed with a male of the L10 strain, and then Jingsong females were mated to (Jingsong x L10) $\mathrm{F}_{1}$, or other backcross (BC) generation (6 in total), males in order to evaluate their economic characteristics. In each generation, 2 SSR markers (F10316 and F10568, located on either side of $n s d-Z$; Li et al., 2006) were 
used to detect the genotype of male moths after they mated with Jingsong females. Amplification of both markers in 1 individual implied that the segments of the 2 chromatids from the 2 markers were highly likely to have come from both the L10 and the Jingsong strains, and this individual would therefore likely possess the $n s d-Z$ gene. Otherwise, Jingsong-type homozygous animals were discarded, because if both chromatids were from the Jingsong parent, the animal would likely not possess the $n s d-Z$ gene. Self-mating within a generation was carried out in the $\mathrm{BC}_{6}$ generation, and these offspring were fed DNV-Z. Individuals with good economic characteristics that were not susceptible to DNV-Z were selected and self-mated to generate the next generation $\left(\mathrm{BC}_{6} \mathrm{~F}_{3}\right)$. Thus, a new silkworm race with good economic characteristics and no susceptibility to DNV-Z was bred.

\section{Virus inoculation and diagnosis}

Dried silkworm midgut containing DNV-Z was ground in distilled water until it turned into a dense solution. The solution was filtered through gauze and centrifuged $(3500 \mathrm{rpm}$, $20 \mathrm{~min}$ ). After adding an equal volume of $7 \%$ acetic acid to the supernatant, the solution was incubated at $25^{\circ} \mathrm{C}$ for $40 \mathrm{~min}$, followed by adjustment to $\mathrm{pH} 7.0$ and progressive dilution to a $0.5 \%$ tissue solution. Bioassays were conducted at $25^{\circ} \mathrm{C}$. DNV-Z was fed to newly hatched larvae of the $\mathrm{BC}_{6} \mathrm{~F}_{3}$ generation for the first instar, followed by rearing on uncontaminated fresh mulberry leaves from the second instar onward. Normally, silkworms susceptible to DNV-Z develop very slowly and do not survive through the third instar. After the third instar, all sick silkworms were checked for DNV-Z, using a PCR-based method, to verify whether they were infected (Hou et al., 2005).

\section{RESULTS}

\section{DNV-Z resistance and MAS of populations}

In each $\mathrm{BC}$ generation, 12 male moths with good economic characteristics were selected to determine their genotypes with respect to the 2 co-dominant markers (Table 1). Approximately 4 to 6 moths were heterozygous for these 2 markers in each generation, and were selected as parents of the next generation (Table 2). A total of 24 pairs from the $\mathrm{BC}_{6}$ generation, which demonstrated good economic characteristics, were mated to produce the $\mathrm{BC}_{6} \mathrm{~F}_{2}$ generation. Parents of 5 pairs were heterozygous at the 2 SSR loci, and their offspring were reared with DNV-Z-contaminated mulberry leaves to select for homozygous non-susceptible to $\mathrm{DNV}-\mathrm{Z}$ individuals. The individuals selected to produce the $\mathrm{BC}_{6} \mathrm{~F}_{3}$ generation were also assessed with regard to these 2 SSR markers; only 1 male showed heterozygosity at the F10568 locus, and the others showed L10-type homozygosity at both loci. The $\mathrm{BC}_{6} \mathrm{~F}_{3}$ population was again fed DNV-Z, and proved to be non-susceptible to DNV-Z. Figure 1 shows the genotypes at the F10316 locus of all of the backcrossed male parents and of the non-susceptible individuals selected for rearing in each generation. Figure 2 shows the genotype at the F10316 locus of randomly selected $\mathrm{BC}_{6} \mathrm{~F}_{2}$ individuals. The ratio of the Jingsong type, heterozygotes, and the L10 type was consistently found to be 1:2:1. 
Table 1. The co-dominant markers used in the marker-assisted selection.

\begin{tabular}{lll}
\hline Marker symbol & F Primer sequence $\left(5^{\prime}-3^{\prime}\right)$ & R Primer sequence $\left(5^{\prime}-3^{\prime}\right)$ \\
\hline F10316 & GCGATAAGACCGCCTATTGAAC & GTGTATTAGGCACGAGAACTGACG \\
F10568 & TCGTCCTACACTTGCGGGTT & TGTTTCGTCAAGTCTGCTCGGT \\
S2511 & TCCAATGTTTCCTAACTAATTCGTGTA & CAAATTAGATCATGGCATATCGAAA \\
\hline
\end{tabular}

\begin{tabular}{|c|c|c|c|c|c|}
\hline \multirow{2}{*}{$\begin{array}{l}\text { Backcrossing } \\
\text { generation }\end{array}$} & \multicolumn{2}{|c|}{ F10316 } & \multicolumn{2}{|c|}{ F10568 } & \multirow{2}{*}{$\begin{array}{c}\text { Number of heterozygotes } \\
\text { at both loci }\end{array}$} \\
\hline & $\begin{array}{c}\text { Number of } \\
\text { heterozygotes }\end{array}$ & $\begin{array}{c}\text { Number of } \\
\text { homozygotes }\end{array}$ & $\begin{array}{c}\text { Number of } \\
\text { heterozygotes }\end{array}$ & $\begin{array}{c}\text { Number of } \\
\text { homozygotes }\end{array}$ & \\
\hline$\overline{\mathrm{BC}_{1}}$ & 6 & 6 (Js type) & 5 & 7 (Js type) & 5 \\
\hline $\mathrm{BC}_{2}$ & 5 & 7 (Js type) & 6 & 6 (Js ype) & 5 \\
\hline $\mathrm{BC}_{3}^{2}$ & 4 & 8 (Js type) & 5 & 7 (Js type) & 4 \\
\hline $\mathrm{BC}^{3}$ & 7 & 5 (Js type) & 7 & 5 (Js type) & 7 \\
\hline $\mathrm{BC}_{5}$ & 6 & 6 (Js type) & 5 & 7 (Js type) & 5 \\
\hline \multirow[t]{2}{*}{$\mathrm{BC}_{6}^{5}$} & 11 오 & 13 (Js type) & 13 오 & 11 (Js type) & 11 오 \\
\hline & $12 \widehat{\partial}$ & 12 (Js type) & $12 \widehat{\partial}$ & 12 (Js type) & $\begin{array}{c}12 \delta^{+} \\
50\end{array}$ \\
\hline $\mathrm{BC}_{2}$ & 0 & 24 (L10 type) & 1 & 23 (L10 type) & 0 \\
\hline
\end{tabular}

*JS = Jingsong.

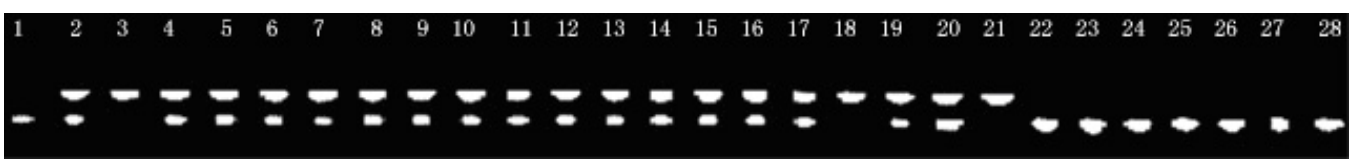

Figure 1. Genotype of the male of each backcrossing generation after detection for the next generation and nonsusceptible individuals of the $\mathrm{BC}_{6} \mathrm{~F}_{2}$ generation at the F10316 locus. Lane $1=\mathrm{L} 10$; lane $2=\left(\right.$ Jingsong $\times$ L10) $\mathrm{F}_{1}$; lane 3 = Jingsong; lanes 4 and $5=\mathrm{BC}_{1}$; lanes 6 and $7=\mathrm{BC}_{2}$; lanes 8 and $9=\mathrm{BC}_{3}$; lanes 10 and $11=\mathrm{BC}_{4}$; lanes 12 and $13=\mathrm{BC}_{5}$; lanes $14-17=\mathrm{BC}_{6}$; lanes $18-21=$ susceptible individuals of the $\mathrm{BC}_{6} \mathrm{~F}_{2}$ generation; lanes $22-28=$ non-susceptible individuals of the $\mathrm{BC}_{6} \mathrm{~F}_{2}$ generation.

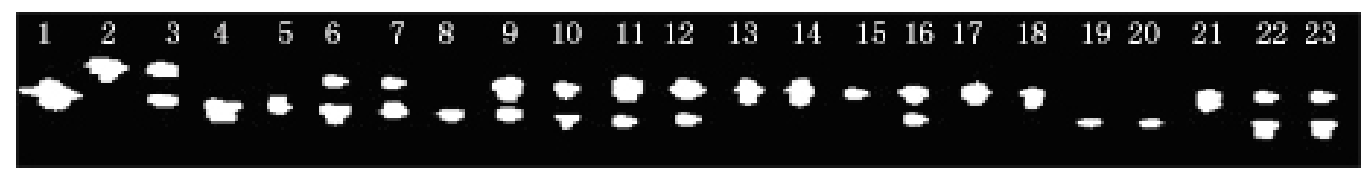

Figure 2. Genotypes of randomly selected individuals of the $\mathrm{BC}_{6} \mathrm{~F}_{2}$ generation at the F10316 locus. Lane $1=$ L10; lane 2 = Jingsong; lane 3 = (Jingsong $x$ L10) $\mathrm{F}_{1}$; lanes $4-23=$ randomly selected individuals of the $\mathrm{BC}_{6} \mathrm{~F}_{2}$ generation.

\section{Economic characteristics of each generation}

Using the L10 strain as the resistant parent, the Jingsong strain was used as a recurrent parent to improve the new silkworm strain's economic characteristics, and co-dominant SSR markers were used to ensure that the $n s d-Z$ gene would not be lost during backcrossing. As shown in Table 3, the economic characteristics of the new strain were similar to those of the parent Jingsong strain. 


\begin{tabular}{|c|c|c|c|c|c|c|c|c|}
\hline Strain/generation & Year & $\begin{array}{l}\text { Duration of } \\
\text { 5th larvae } \\
\text { (day:hour) }\end{array}$ & $\begin{array}{c}\text { Duration of } \\
\text { feeding period } \\
\text { (day:hour) }\end{array}$ & $\begin{array}{c}\text { Cocoon } \\
\text { weight }(\mathrm{g})\end{array}$ & $\begin{array}{c}\text { Cocoon shell } \\
\text { weight }(\mathrm{g})\end{array}$ & $\begin{array}{c}\text { Ratio of } \\
\text { cocoon shell } \\
(\%)\end{array}$ & $\begin{array}{c}\text { Ratio of } \\
\text { cocoon } \\
\text { mortality }(\%)\end{array}$ & $\begin{array}{c}\text { Larva-pupa } \\
\text { survival rate } \\
(\%)\end{array}$ \\
\hline $\mathrm{F}_{1}$ & $2006 \mathrm{Au}$ & $6: 18$ & $21: 06$ & 1.283 & 0.227 & 17.69 & 4.32 & 91.33 \\
\hline $\mathrm{BC}_{1}$ & $2007 \mathrm{Sp}$ & $7: 00$ & $22: 12$ & 1.591 & 0.362 & 22.75 & 3.87 & 96.00 \\
\hline $\mathrm{BC}_{2}$ & $2007 \mathrm{Au}$ & $7: 12$ & $23: 06$ & 1.741 & 0.411 & 23.61 & 3.45 & 95.67 \\
\hline $\mathrm{BC}_{3}^{2}$ & $2008 \mathrm{Sp}$ & $8: 00$ & $23: 18$ & 1.882 & 0.452 & 24.02 & 2.23 & 96.86 \\
\hline $\mathrm{BC}_{4}^{3}$ & $2008 \mathrm{Au}$ & $7: 12$ & $23: 00$ & 1.688 & 0.401 & 23.76 & 4.67 & 91.23 \\
\hline $\mathrm{BC}_{5}$ & $2009 \mathrm{Sp}$ & $8: 12$ & $25: 00$ & 1.822 & 0.441 & 24.20 & 4.32 & 94.88 \\
\hline $\mathrm{BC}_{6}^{5}$ & $2009 \mathrm{Au}$ & $7: 18$ & $24: 00$ & 1.791 & 0.428 & 23.90 & 8.55 & 82.89 \\
\hline $\mathrm{BC}_{6}^{6} \mathrm{~F}_{2}$ & $2010 \mathrm{Sp}$ & $8: 00$ & $24: 18$ & 1.876 & 0.463 & 24.68 & 6.75 & 89.73 \\
\hline $\mathrm{BC}_{6} \mathrm{~F}_{3}^{2}$ & $2010 \mathrm{Au}$ & $8: 12$ & $25: 00$ & 1.968 & 0.491 & 24.95 & 2.67 & 96.59 \\
\hline Jingsong & $2010 \mathrm{Au}$ & $8: 00$ & $24: 18$ & 1.861 & 0.458 & 24.61 & 7.26 & 88.06 \\
\hline $\mathrm{BC}_{6} \mathrm{~F}_{4}$ & $2012 \mathrm{Sp}$ & $8: 06$ & $24: 18$ & 1.931 & 0.483 & 25.01 & 2.88 & 95.41 \\
\hline Jingsong & $2012 \mathrm{Sp}$ & $8: 12$ & $25: 00$ & 2.052 & 0.511 & 24.90 & 2.88 & 95.41 \\
\hline $\mathrm{L} 10$ & $2012 \mathrm{Sp}$ & $4: 00$ & $17: 08$ & 0.630 & 0.070 & 11.11 & 2.90 & 97.00 \\
\hline
\end{tabular}

$\mathrm{Sp}=$ spring; $\mathrm{Au}=$ autumn.

\section{Homozygosity in male moths of each backcrossed generation}

Two SSR markers that showed polymorphism between Jingsong and L10 were selected from each linkage group of the SSR linkage map (Miao et al., 2005) to detect homozygosity of the backcrossed males throughout the breeding procedure. An average of 12 linkage groups were homozygous for Jingsong in the $\mathrm{BC}_{1}$ generation, and an average of 19 linkage groups were homozygous for Jingsong in the $\mathrm{BC}_{2}$ generation. $\mathrm{By}$ the $\mathrm{BC}_{3}$ and $\mathrm{BC}_{4}$ generations, the number of homozygous linkage groups increased to 23 and 25, respectively (Figure 3). Only 1 marker of 10 individuals was found to be heterozygous in the $\mathrm{BC}_{6}$ generation, while the others were all homozygous, except those linked to $n s d-Z$ (data not shown).

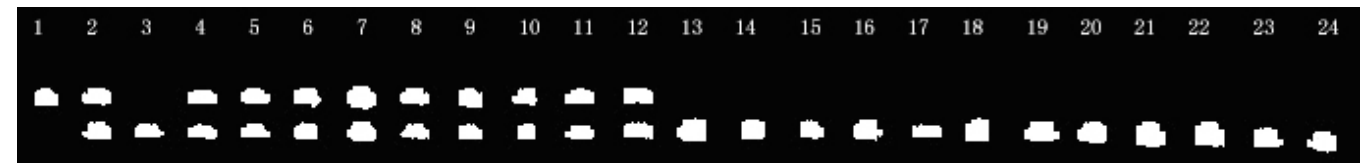

Figure 3. Genotype of the male of each backcrossing generation at the $\mathrm{S} 2511$ locus. Lane $1=\mathrm{L} 10$; lane $2=$ (Jingsong $\mathrm{x}$ L10) $\mathrm{F}_{1}$; lane 3 = Jingsong; lanes 4- $6=\mathrm{BC}_{1}$; lanes $7-9=\mathrm{BC}_{2}$; lanes $10-12=\mathrm{BC}_{3}$; lanes 13-15= $\mathrm{BC}_{4}$; lanes 16-18= $\mathrm{BC}_{5}$; lanes 19-24 $=\mathrm{BC}_{6}$.

\section{DISCUSSION}

During sericulture, disinfection is used to eliminate pathogens. Several different chemical agents are generally used, many of which are harmful to both humans and the environment. Nonetheless, pathogens cannot be completely eliminated from rearing houses, and silkworm diseases occur frequently, especially in rural areas. Densonucleosis is common in rural areas, especially in the autumn, and the $n s d-Z$ allele controls non-susceptibility to DNV$Z$. The best way to control the spread of such diseases is to breed silkworm varieties that are resistant to pathogens.

It is possible to breed commercial silkworm strains that are not susceptible to DNV-Z, 
and such strains have been bred using crossing methods (Eguchi et al., 1998; Li et al, 2001b). For example, the virus was fed to silkworm larvae throughout classical crossing procedures to ensure that the resistance gene would not be lost during backcrossing. Although it is relatively easy to make $n s d-Z$ homozygous as a recessive gene, a good breeding design is necessary to ensure that the gene will not be lost. Furthermore, special care is necessary when feeding the virus to silkworms; i.e., using special rooms and appropriative tools to avoid infecting other silkworms, and rearing under sterilized conditions.

MAS has been widely used in crop breeding, along with developments in molecular biology, although it has not yet been widely applied in silkworm breeding. We screened for SSR markers linked to $n s d-Z$, and adopted the nearest 2 to select for silkworms that possess the $n s d-Z$ gene. A new silkworm strain that was non-susceptible to DNV-Z was bred after 6 generations of backcrossing, and its economic characteristics were similar to its recurrent (Jingsong) parent.

The key to successful MAS is to select a tightly linked marker. The best option would be the gene itself or part of it, because this would prevent recombination during backcrossing, thus avoiding errors in selection. In our screening, the nearest SSR markers were $4.4 \mathrm{cM}$ away from the $n s d-Z$ gene, which suggested a high probability of losing $n s d-Z$ during backcrossing if only 1 marker were used. Thus, we used 2 markers, located on either side of the $n s d-Z$ gene. In a previous study, no double-recombination occurred among these 3 loci in 190 individuals. Therefore, we decided to rear offspring of fathers who expressed heterozygosity at both loci. We did observe recombination during backcrossing with these 2 markers, however (Table 3), and these individuals were discarded. Fortunately, there was not an important economic characteristic locus (except $n s d-Z$ ) located between these 2 loci. Otherwise, it would have been difficult to simultaneously improve economic characteristics while selecting for resistance by backcrossing.

In our study, individuals were detected after eclosion, and mated to females to produce the next generation. The silkworm body is small, and could easily be fatally damaged if tissues or blood are sampled for genotype detection. In the future, we would like to develop a method that allows detection of the larval genotype without the need to sample tissues. With such a method, it would only be necessary to rear a small group of individuals, thereby saving costs and improving efficiency.

In conclusion, we used SSR markers as tools to select for silkworms that are not susceptible to DNV-Z. A new non-susceptible silkworm strain was bred after 6 generations of backcrossing, and its economic characteristics were similar to those of its recurrent parent.

\section{ACKNOWLEDGMENTS}

Research supported by the National Natural Science Foundation of China ( $\# 30972145$ and \#30825007), and the Natural Science Foundation of Jiangsu Province (\#BK2009220).

\section{REFERENCES}

Abe H, Watanabe H and Eguchi R (1987). Genetical relationship between nonsusceptibilities of the silk-worm, Bombyx mori, to two densonucleosis viruses. J. Seric. Sci. Jpn. 56: 443-444.

Abe H, Harada T, Kanehara M, Shimada T, et al. (1998). Genetic mapping of RAPD markers linked to the densonucleosis refractoriness gene, nsd-1, in the silkworm, Bombyx mori. Genes Genet. Syst. 73: 237-242.

Abe H, Sugasaki T, Kanehara M, Shimada T, et al. (2000). Identification and genetic mapping of RAPD markers linked to the densonucleosis refractoriness gene, nsd-2, in the silkworm, Bombyx mori. Genes Genet. Syst. 75: 93-96.

Eguchi R, Ninaki O and Hara W (1991). Genetical analysis of the nonsusceptibility to densonucleosis virus in the 
silkworm, Bombyx mori. J. Seric. Sci. Jpn. 60: 384-389.

Eguchi R, Hara W, Shimazaki A, Hirota K, et al. (1998). Breeding of the silkworm race "taisei" non-susceptible to a densonucleosis virus type 1. J. Seric. Sci. Jpn. 67: 361-366.

Goldsmith MR, Shimada T and Abe H (2005). The genetics and genomics of the silkworm, Bombyx mori. Annu. Rev. Entomol. 50: 71-100.

Guo XJ, Qiwan YJ, Hu XF and Wang HL (1985). Studies on the infection site by the densonucleosis virus in the diseased silkworm (Bombyx mori L.) in China. Acta Seric. Sin. 11: 93-98.

Hou CX, Li MW, Gui ZZ, Xu AY, et al. (2005). PCR-based detection of densovirus infection in silkworm (Bombyx mori L.). Int. J. Ind. Entomol. 11: 135-138.

Hu XF, Qian YJ and Wang HL (1984). Studies on infectivity of silkworm densonucleosis virus to some silkworm races. Acta Seric. Sin. 10: 87-90.

Ito K, Kidokoro K, Sezutsu H, Nohata J, et al. (2008). Deletion of a gene encoding an amino acid transporter in the midgut membrane causes resistance to a Bombyx parvo-like virus. Proc. Natl. Acad. Sci. U. S. A. 105: 7523-7527.

Iwashita Y and Chao YS (1983). The development of a densonucleosis virus isolated from silkworm larvae, Bombyx mori, of China. Acta Seric. Sin. 9: 219-222.

Li MW, Yao Q, Hou CX, Lu C, et al. (2001a). Studies on RAPD markers linked to the densonucleosis refractoriness gene, nsd-Z in silkworm, Bombyx mori L. Sericologia 41: 409-415.

Li MW, Hou CX, Yao Q and Chen KP (2001b). Breeding commercial bivoltine silkworm hybrid resistant to Zhenjiang (China) strain of densonucleosis virus (DNV-Z). Sericologia 41: 581-588.

Li MW, Li MH, Miao XX, Lu C, et al. (2005a). Studies on the hereditary properties of SSR marker in silkworm (Bombyx mori L.). Int. J. Indust. Entomol. 11: 49-55.

Li M, Shen L, Xu A, Miao X, et al. (2005b). Genetic diversity among silkworm (Bombyx mori L., Lep., Bombycidae) germplasms revealed by microsatellites. Genome 48: 802-810.

Li M, Guo Q, Hou C, Miao X, et al. (2006). Linkage and mapping analyses of the densonucleosis non-susceptible gene $n s d-Z$ in the silkworm Bombyx mori using SSR markers. Genome 49: 397-402.

Lü HS (1998). Molecular Biology of Insect Viruses. China Agricultural Scientech Press, Beijing.

Miao XX, Xub SJ, Li MH, Li MW, et al. (2005). Simple sequence repeat-based consensus linkage map of Bombyx mori. Proc. Natl. Acad. Sci. U. S. A. 102: 16303-16308.

Ogoyi DO, Kadono-Okuda K, Eguchi R, Furuta Y, et al. (2003). Linkage and mapping analysis of a non-susceptibility gene to densovirus (nsd-2) in the silkworm, Bombyx mori. Insect. Mol. Biol. 12: 117-124.

Qian YJ, Guo XJ, Hu XF and Watanabe H (1985). The serological relationship of Bombyx mori densonucleosis virus from China and Japan. Acta Seric. Sin. 11: 241-242.

Qin J and Yi WZ (1996). Genetic linkage analysis of $n s d-Z$, the nonsusceptibility gene of Bombyx mori to the Zhenjiang (China) strain densonucleosis virus. Sericologia 36: 241-244.

Reddy KD, Abraham EG and Nagaraju J (1999). Microsatellites in the silkworm, Bombyx mori: abundance, polymorphism, and strain characterization. Genome 42: 1057-1065.

Seki H and Iwashita Y (1983). Histopathological features and pathogenicity of a densonucleosis virus of the silkworm, Bombyx mori, isolated from sericultural farms in Yamanashi prefecture. J. Seric. Sci. Jpn. 52: 400-405.

Steele KA, Price AH, Shashidhar HE and Witcombe JR (2006). Marker-assisted selection to introgress rice QTLs controlling root traits into an Indian upland rice variety. Theor. Appl. Genet. 112: 208-221.

Tautz D (1989). Hypervariability of simple sequences as a general source for polymorphic DNA markers. Nucleic Acids Res. 17: 6463-6471.

Watanabe H, Kawase S, Shimizu T and Seki H (1986). Difference in serological characteristics of densonucleosis viruses in the silkworm Bombyx mori. J. Seric. Sci. Jpn. 55: 75-76.

Yau YY, Santos K and Simon P (2005). Molecular tagging and selection for sugar type in carrot roots using co-dominant, PCR-based markers. Mol. Breed. 16: 1-10. 